\title{
Role of Rampak Yakso Dance in Cutting Dreadlocks Ritual Ceremony in Dieng Banjarnegara Central Java
}

\author{
Renistiara Medilianasari ${ }^{1, *}{ }^{*}$ Trie Hartiti Retnowati ${ }^{1}$
}

\author{
Graduate School of Arts Education, Yogyakarta State University Yogyakarta, Indonesia \\ *Corresponding author. Email: renistiara@gmail.com
}

\begin{abstract}
Art closely grows within the community, holding the function of both entertainment and ritual. The art presented in the ceremony does not only have an aesthetic meaning but function as a ceremony comprising myths. Dieng communities in Central Java, Indonesia has an annual dreadlock cutting ritual with Rampak Yakso dance accompanying. The dance features a group of men dressed in a traditional costume to bodyguards the ceremony to the end. This study aims to describe 1) the dreadlocks cutting rituals, 2) the role and function of the Rampak Yakso dance in the rituals, and 3) the meaning and symbol of the Rampak Yakso dance. This study employs a qualitative approach with a semiotic method derived from Roland Barthes's theory. Data were obtained through observation and interviews and analyzed qualitatively. The results suggest that 1) dreadlocks cutting ceremonies have been the tradition of Dieng community performed once a year for children with dreadlocks. 2) The role and function of the Rampak Yakso dance in this ritual acts as a safeguard in the ceremonial process, and 3) it symbolizes heroism, clearly exposed by the dance moves and the costume worn.
\end{abstract}

Keywords: dance, ritual, Rampak Yakso, dreadlocks

\section{INTRODUCTION}

Indonesia societies have various beliefs that leads to the presence of custom ritual ceremony. Various tribes spreading all over Indonesia, from one region until from one island to another island have differences which are based on the tradition or customs grows in local neighborhood. Ritual ceremony is descended from generation to generation, from the ancestors to next the generation to keep the tradition, customs and beliefs they have are not gone or vanished.

The ritual existence in all regions is a form of symbol in religion and also human culture symbolism. The symbolic act in religious ceremony is a vital part and cannot just be abandoned. Humans need to do something that symbolizes a communication with God. Besides in religion, the symbolism in customs is significantly visible, custom ceremonies that are the heritage of generation to generation from old generations to the young ones [1].

In every region in Indonesia has their own rules in running the ritual ceremony they have. Kinds of ceremony in society life are: marriage ceremony, funeral ceremony, pregnancy remembrance ceremony, gratitude ceremony and other ritual ceremonies. Generally, ceremony has sacred value by the society of that culture supporter. In the middle of ceremony, there are parts which support the occurrence of ceremony, such as dance, which has special role in the process of ritual ceremony occurs.

Some ritual ceremonies which cannot be separated from their region's special dance are considered to have certain role and function. Naturally, every dance has its own role. In every move, dance has 'something', something can be defined as uniqueness and attractiveness in every move. In this point, dance has something which finally has function.

In individual and social life, dance is a need or tool used to convey soul expression in its relationship with living environment importance. Dance is not only seen with its beauty alone, but dance can be seen based on its function. One of many functions of dance is ceremony dance. The main function of dance in traditional ceremony can be seen from the social life of society supporters, whether in vertical or horizontal. In vertical, the function of this deep ceremony dance wants to create a balance between humans and The Creator, ghosts and supranatural force. That balance will bring happiness and peace for society of ceremony supporter. The function of traditional ceremony in horizontal is more normative, that is to keep balance in every social relationship among the people as the main supporter of ceremony. According to its function, dance can be classified into three, they are ceremony dance, entertainment dance and performance dance. Ceremony dance as offering and worship media toward higher power which aim to obtain protection or to cast out for the sake of the safety, happiness and prosperit lives of society [6].

Function of dance according to Soedarsono is stated as ceremony function, if that dance has features, they are a) the time is selected, is danced in important ceremonies b) selected place, it is a place to dance has been decided in house, a building or in a yard c) chosen dance, it is the dancers are determined by the chief or event leader d) accompanied with offerings, it is a thing that becomes important thing to offered to the ghosts or people who are believed [6]. Rampak Yakso dance as a support of cutting dreadlocks ritual ceremony 
visually gives deeper meaning to the meaning and occurance of ritual ceremony.

Based on the interesting background condition, then encourages the writers to review further, it is because every ritual ceremony occurs has their own rules and uniqueness. These diversities makes an attractiveness even a tour that is loved by many people. The occurance of ceremony in every region also has important embodiment of Indonesia culture preservation in industry era which are hustle and bustle with the use of technology based on computer, robot and internet network. Therefore, a paper entitles 'Role of Rampak Yakso Dance in Cutting Dreadlocks Ritual Ceremony in Dieng, Banjanegara, Central Java' is studied with its research problems as follows: 1) what is cutting dreadlocks ritual ceremony looks like? 2) how is the role and function of rampak yakso dance in cutting dreadlocks ritual ceremony?, 3) what is symbolic meaning in Rampak Yakso dance in cutting dreadlocks ritual ceremony? The purpose of this research is to discover cutting dreadlocks ritual ceemomy, discover the role and also function of rampak Yakso Dance in cutting dreadlocks ritual ceremony and discover the meaning and symbol of Rampak Yakso dance in cutting dreadlocks ritual ceremony. The advantages of this research are expected as knowledge reference about cutting dreadlocks ritual ceremony, particularly in Rampak Yakso Dance in Dieng, Banjarnegara Regency, Central Java.

\section{LITERATURE REVIEW}

\subsection{Dance}

In Jazuli, dance is defined as human soul expressions which are expressed with beautiful ryhtmic moves. Dance is not only as a tool to express but also as means of communication to convey and state comments about life reality through moves of a dance. As means of communication, dance through motion-space-time carries certain mission or message to be understood by the lovers, while body is a tool to communicate from the dancer. Thus, the success or unsuccess of communication through dance is also determined by the dancer's body move in doing every move. Therefore, it can be concluded that move is the element of dance. But move in here does not mean real move based on reality which has experienced stilation or distortion which are expressive. Based on the the meaning, dance has some aspects, they are [2]

\subsection{Move}

Move is the primary element of dance. In daily lives, what is meant by move is the change move of an object from one position to another position. However, in dance, move does not only mean the position change, but also expression change (mimic) of the doer. Moves in dance is seen very detail. Every part our body has its own move in dance. From the move of head, eyeball, shoulder, hands, fingers, wrist, hip and feet, all of them move on the nature of beauty. Moves in dance have various characteristics, for instance moves that are quick, slow, weak, soft, gentle, flowing, strict and broken off.

According to Kusnadi, dance moves are categorized into two kinds they are meaningful move and pure move [4]. Meaningful move is a move to express meaning explicitly. For instance, the move of an angry man or move of crying man. Pure move is a move which its functions are only for beauty that does not contain certain meaning. This pure move does not have special meaning but as a dance ornament so it looks more beautiful.

\subsection{Cosmetic}

Cosmetic is an important element in a dance art. The functions of make up are to change character, to strengthen expression and also to be a differentiator between one characters with another. Dance cosmetic is technique use of cosmetic tools on dancers' face. Generally, cosmetic for dance art also includes dancers' hair styling. According to Kusnadi, term of cosmetic comes from 'tata' (in Bahasa) means rules and 'rias' means to form or paint to make theme and dance character will be performed suitable [4].

\subsection{Costume}

Costume are dance element which relates each other to make up. Costume is all rules or regulations about costume or fashion use in dance. Costume is all equipment worn by a dancer. Function of costume in dance is to form imagination based on the role being performed. Dance costume selection is usually based on theme, artistic consideration and also the dancers' freedom in moving [4]. Dance costume that is suitable with dance theme can increase aesthetic value of dance art performance. Besides being suitable with dance theme, basically dance costume must be good to see and does not interfere dancers' moves.

\subsection{Custom Ceremony}

Ceremony is an activity system or series or action that are arranged by applicable custom or law in society related to various permanent occasions that usually occur in society involved [3].

Kind of ceremony in society life are: birth ceremony, marriage ceremony, funeral ceremony and chief inauguration ceremony. Generally, ceremony has sacred valued by the society of that culture supporter. Custom ceremony is a ceremony that is done from generation to generation by its supporters in a region. Therefore, every region has its own custom ceremony, such as custom ceremony of marriage, birth and death.

Custom ceremony done has various elements. Koentjaraningrat states there are some elements related to having custom ceremony, they are:

- The place where the ceremony held

The place used to have a ceremony is usually a sacred place or holy, not everyone can visit that place. That place is only visited by the people who are authorized, in this case is the ones who are involved in having the ceremony, such as the ceremony leader.

- $\quad$ The time for having the ceremony

Time for having ceremony is some certain times which is considered right to have the ceremony.

- Ceremony objects or tools

Ceremony objects or tools in having a ceremony are something which must be there, such as offerings which functions as a tool in a custom ceremony. 
- The people involved in it

The people involved in it are those who act as the ceremony leader and some people who understand about custom ceremony ritual [3].

\subsection{Cutting Dreadlocks Ceremony}

Generally, cutting dreadlocks ritual fulfills characteristics required in a tradition ceremony, they are:

- Determined time occurance,

- Using offerings,

- Ceremony place,

- Involves many people as the ritual doers.

Those things are in line with Koentjaraningrat statements which states that religion ceremony that can be categorized as ritual at least fulfill four elements, they are ceremony place, ceremony occurance time, ceremony objects and ceremony doers [7].

Cutting dreadlocks is done by local religious leaders or public leaders which are considered has influence to the local society's life. Ritual activities are started by visiting the place of ancestors or sacred place to ask for guidance and ask for safety to the children whose hair will be cut and their family. After that, the dreadlocks have been cut are covered with mori cloth and immersed in Tulis River or Serayu River. After cutting dreadlocks ritual is done, gratitude ceremony is the next thing to do as a thankful expression to God for ritual has been done safely and begging safety for the children and family.

\section{METHOD}

Method employed in this research was semiotic method. Ethimologically, term of semiotic comes from Yunani word 'Semeion' which means sign. Sign is defined as something of social convention which was previously built can be considered to represent something else. Terminologically, semiotics can be identified as a science which studies a series of objects, events, all cultures as sign. Thus, it can be concluded that semiotics is science or analysis method to study sign. The scopes of semiotics study how humans define things, meaning object, not only to bring information but also to constitute the structured system of sign [5].

\section{ROLAND BARTHES' SEMIOTICS}

According to Roland Barthes, semiotics is a science or anylisis method to study sign. Barthes divides two meanings (signification) of semiotics, they are denotation and connotation. Denotation is descriptive or literal level or meaning has been approved by all culture members, and connocation is a meaning resulted by the relationship between signifier and culture in broad, which cover beliefs, behavior, work frame and ideology of a social formation. Semiology, basically in Barthes' term is to learn how humanity use things, to signify in this case cannot be mixed to communicate. To signify means that the objects want to communicate and laso to constitute the structured system of a sign [5].

\section{DISCUSSIONS}

Cutting dreadlocks ceremony ritual is a tradition done once a year by society in Dieng Village, Banjarnegara Regency. This ceremony is done because its purpose is to turn the children whose hair is dreadlock into ordinary hair as it was. Every year in Dieng Village, it has special children who have dreadlocks. It happens not because they intentionaly want to have their hair dreadlocked but it already has happened since long time ago. Myths happens when the society believes in the origin of the children's dreadlocks came from an ancestor named Kolodete. Kolodete is a magical indigenous person of Dieng Village, he had dreadlock and loved children very much. Then when he died muksa (vanish), the children with dreadlock are believed as his descendants.

A child who has dreadlocks will not be able to lose his dreadlocks if he is not recovered yet in cutting dreadlocks ceremony. When he attempts to cut his hair outside ceremony tradition, then the dreadlocks will reappear. There are so many pros and cons arguments and opinion to this occurance in Dieng Village. Some relate to with scientific things and some also relate it to mystical things. Nevertheless, tradition is remained run. Cutting dreadlocks ceremony becomes attractive tour destination for tourists who are curious or just want to see the process of cutting dreadlocks. This kind of cultural tour will rebuild the love for Indonesia richness who gets replaced in industry era. However, industry era also gives positive impact for its users broadly to be able to more easily use about information of Indonesia culture richness. In its perseverance, this ritual ceremony has a potential to be a tour destination with its name event "Dieng Culture Festival". Generally, this ceremony is held around August in Dieng Village, Banjarnegara Regency.

There are some steps before the ceremony begun, the ceremomy is started from kirab process that is done by the village elders and the dreadlocks boys from townhall to darmasala. Darmasala is a place where the children with dreadlocks will be washed (jamasi) with seven springs have been prepared by the elders of the village. When washing process is done, they continue kirab (parade) process to the cutting location, which is Arjuna Temple. Before cutting process, first they mention what they wish for that later will be fulfilled by the ceremony supporters. Most of them wish for toys. However, it is often to see that they ask for strange request such as white mice and so forth

In the process of cutting dreadlocks ceremony performed some local arts are performed. The art which is originited from Dieng Village will be put in parade and performed such as Rampak Yakso dance, Topeng Lengger dance and other arts. Rampak Yakso dance is a dance perfomed in a group and is performed by male dancers. This is because Rampak Yakso dance tells a group of giants.

\subsection{Wholy Meaning interpretation in Rampak Yakso Dance}

Rampak Yakso dance is a dance perfomed in the time of cutting dreadlocks ceremony ritual occurs. Besides having entertaining side which has its own meaning in the time cutting dreadlocks ceremony ritual occurs, Rampak Yakso Dance, in denotation, is used as a guardian symbol during the cutting dreadlocks ceremony ritual occurs which is started from kirab process until 
ceremony procession to the children who will be recovered ends. This guardian symbol was taken from a tale which was believed as myth by society which came from local folktales that the blind giant was the incarnation of the birth of Gatutkaca wayang figure which was believed that could keep the children with dreadlockes. Connotation of Gatutkaca in here is the good and knight-hearted man so it is suitable to good character of Gatutkaca who does the guardian.

The story was begun from the belief that long time ago in heaven there was a knight named Patih Skepu who was a buta (giant), but he did something bad, that he destroyed the system of Njuggring Seloko heaven. Then Bathara Narada had intention to take Gatutkaca who at that time was in form of baby giant and believed as a knight. Gatutkaca was the son of Bima and Dewi Arimbi. Bathara Narada tended to place Gatutkaca in a crater to fight Patih Skepu led by Prabu Kolo Pracono from Giling Wesi Kingdom. After being placed in the crater, Gatutkaca then transformed into a handsome and charming knight.

In cutting dreadlocks ritual ceremony, Rampak Yakso is believed as the incarnation of Gatutkaca who can give a guard to the dreadlock's children. This guard is done in parade time which is started from townhall through darmasala in which there is sendang sedayu that becomes a place for dreadlocks children will be washed firstly. Then it continues to Arjuna Temple area, where there are some temples in it, such as Semar Temple, Puntadewa Temple, Arjuna Temple and Sembadra Temple.

\subsection{Meaning Interpretation from Performance form in Rampak Yakso dance}

Moves danced in Rampak Yakso dance has denotation refers to traditional dance moves which mostly use blind moves with features of broad move volume, two hands are lifted up and has diverse rampak move and free. This leads to blind sign shown at that dance which is interspersed by some attractions done by the dancers.

Costume used in Rampak Yakso dance is identical to red vest, panji pants, cloths and accessories for buta (giant). Rampak Tari dance costume has connotation, such as red vest that symbolizes bravery, that is character possessed by a knight. Accessories for buta become identity giving description that buta is someone who is magical and brave.

Cosmetics used in Rampak Yakso dance is fierce cosmetic which emphasizes that red is a majority color. This is as a sign that buta is someone who is brave and here he has a job to keep and do a guardian.

\section{CONCLUSIONS}

From the research results, aspects can be seen from rampak yakso dance are dance, costume, cosmetics and move which symbolize powerful heroic meaning and also shown by dancers. Besides, there are denotation meaning and connotation meaning have been shown and have deep meaning for local society.

The research result's conclusions are: 1) cutting dreadlock ceremony is Dieng society's tradition which is done once a year to the children with dreadlocks, 2) the role and function of Rampak Yakso dance in cutting dreadlocks ceeony is a part of guarding in ceremony process, and 3) Rampak Yakso dance symbolizes heroic in cutting dreadlocks ceremony, this heroic meaning is so powerful performed with dance or worn costumes. Heroic meaning is supported from several factors scuh as dance meaning which has history, in which the dancers are a symbol who are believed as the knights who can protect the procession of cutting dreadlocks ceremony ritual, then the costume worn is a portrait of wayang figure as a giant. The frightening impression is as a sign that he is the feared man, next on the cosmetic and also supporting moves with the appearance of a giant

If we look back from this paper, then heroic meaning can be concluded from the meaning of rampak yakso dance in cutting dreadlocks ceremony ritual.

\section{REFERENCES}

[1] Budiono, Herusatoto. "Simbolisme dalam Budaya Jawa [Symbolism in Javanese Culture]." Yogyakarta: Hanindita Graha Widia (2000).

[2] Jazuli, Muhammad. "Telaah teoritis seni tari [A theoretical study of dance]." Semarang: IKIP Semarang Press, SENI TARI-LAMPIRAN A (1994). Unpublished

[3] Koentjaraningrat, Sejarah Teori Antropologi [History of Anthropological Theory]. "Jil. I." (1980).

[4] Kusnadi, "Penunjang Pembelajaran Seni Tari [The support of the Dance Art Learning". PT Tiga Serangkai Pustaka Mandiri: Solo, 2009.

[5] Sobur, Alex. Semiotika komunikasi [Semiotics of communication]. Remaja Karya, 2017.

[6] Soedarsono, "Pengantar Pengetahuan Tari 1 [Introduction to Dance Knowledge I]". Departemen Pendidikan dan Kebudayaan: Jakarta, 1982.

[7] Koentjaraningrat, "Manusia dan Kebudayaan Indonesia [Human and Indonesian Culture]", Djambatan: Jakarta, 1984. 